\title{
Financial Shocks and Financial Well-Being: What Builds Resiliency in Lower-Income Households?
}

\author{
Sam Bufe ${ }^{1} \cdot$ Stephen Roll ${ }^{1}$ (D) Olga Kondratjeva ${ }^{1} \cdot$ Stephanie Skees ${ }^{1}$. \\ Michal Grinstein-Weiss ${ }^{1}$
}

Accepted: 11 October 2021 / Published online: 21 October 2021

(C) The Author(s), under exclusive licence to Springer Nature B.V. 2021

\begin{abstract}
Households in the U.S. regularly experience unexpected negative income or expense shocks, and low- and moderate-income households experience these shocks at disproportionately high rates. Relatively little is known about the impact these shocks have on households' subjective sense of financial well-being, and how access to different types of liquidity (e.g., liquid assets, credit cards, social resources, and income flows) can mitigate the impact of these shocks on subjective financial well-being. To address these gaps in the literature, this paper uses data from a two-wave survey administered to 3,911 low- and moderate-income tax filers in 2018. Applying a difference-in-difference analysis, we find that the experience of an income shock between survey waves was associated with a large decline in subjective financial well-being, while the experience of an expense shock was associated with a more modest decline. Relatively liquidity-constrained households tended to be more negatively impacted by shocks than their counterparts, though not all sources of liquidity were equally as effective in buffering households against shocks. The findings of this paper point to the need for policymakers and program administrators to develop tools that can facilitate access to different types of liquidity to offset different financial risks for households.
\end{abstract}

Keywords Financial well-being $\cdot$ Economic shocks $\cdot$ Liquid assets $\cdot$ Resilience $\cdot$ Lowincome

Stephen Roll

Stephen.roll@wustl.edu

Sam Bufe

sambufe@wustl.edu

Olga Kondratjeva

okondratjeva@wustl.edu

Stephanie Skees

slskees@wustl.edu

Michal Grinstein-Weiss

michalgw@wustl.edu

1 Social Policy Institute, Brown School, Washington University in St. Louis, St. Louis, USA 


\section{Introduction}

Prior to COVID-19, the United States economy was experiencing rising incomes and relatively high employment (Bureau of Labor Statistics, 2019; U.S. Bureau of the Census, 2017), yet many households struggled to make ends meet; an experience disproportionately faced by low- and moderate-income (LMI) households. These households face a combination of tight budgets (Schanzenbach et al., 2016), low levels of liquid assets (Board of Governors of the Federal Reserve System [BGFRS], 2016) and high rates of unplanned financial shocks (e.g., Hannagan and Morduch, 2015) such as unexpected drops in income or increases in expenses. Each of these financial circumstances, in isolation or together, place LMI households at increased risk for an array of material, medical, and financial hardships including missed housing payments, skipped medical care, and reduced food consumption (Despard et al., 2018; Heflin, 2016; Leete and Bania, 2010; McKernan et al., 2009). These hardships are associated with an array of adverse conditions including mental and physical health issues (Heflin and Iceland, 2009; Palar, Laraia, Tsai, Johnson, and Weiser, 2016; Sullivan et al., 2008; Whittle et al., 2015), child developmental problems (e.g., Gershoff, Aber, Raver, and Lennon, 2007; Rauh et al., 2004), and housing insecurity (Desmond and Kimbro, 2015).

Much of the extant research literature concerning negative financial shocks focuses on the relationship between these shocks and relatively objective measures of financial security and well-being like being able to cover essential expenses or put enough food on the table. However, little is known about the impact these shocks have on households' subjective sense of financial well-being. This gap in the research is likely due in part to the lack of a valid and rigorous measure a subjective sense of financial well-being. To address this, the Consumer Financial Protection Bureau (CFPB) has recently developed a comprehensive definition of financial well-being in U.S. households, as well as a way of measuring this construct. The CFPB defines subjective financial well-being in terms of a household's control over their day-to-day and month-to-month finances, their capacity to absorb a financial shock, their feeling of being on track to meet their financial goals, and having enough financial freedom to make choices that enhance their lives (CFPB, 2015), and research using this definition is becoming increasingly common. This research is predominately correlational (CFPB, 2017a; Sun et al., 2018; Bufe et al., 2019), and there is limited research on the degree to which different household experiences-such as financial shocks - are causally related to changes in subjective financial well-being. Moreover, though extant research suggests that access to emergency savings is among the strongest correlates of subjective financial well-being, there is very limited evidence on how access to emergency savings and other types of liquidity can modulate the relationship between financial shocks and financial well-being.

To address this gap in the research, this study seeks to answer the following research questions:

(1) Which types of financial shocks have the greatest impacts on the self-assessed financial well-being of LMI households?

(2) To what extent do household income flows, social networks, liquid savings, and access to credit mitigate the negative effects of financial shocks on the subjective financial well-being of LMI households? 
To conduct this analysis, we employ a difference-in-differences design that incorporates propensity score weights to correct for potential endogeneity in the experience of financial shocks. We then examine the heterogeneous effects of these shocks based on households' access to the different forms of liquidity. We find that income shocks are by far the most impactful to an LMI household's sense of financial well-being, as compared to expense shocks or medical shocks. We also observe interesting relationships between the impact of these shocks and access to different financial resources. Households with relatively low incomes and households that could not rely on friends and family in the event of an emergency experienced disproportionately large decreases in subjective financial well-being in the event of expense shocks, whereas households with relatively high incomes experienced disproportionately large decreases in subjective financial well-being in the event of income shocks. Furthermore, households with access to credit cards experienced larger declines in subjective financial well-being in the event of income and expense shocks than households without access to credit cards. This pattern may point to a complex interaction between the experience of financial shocks, credit usage, and a sense of financial well-being.

This study makes several key contributions to the literature on subjective financial well-being and financial volatility. First, we build on the limited literature surrounding the relationship between financial shocks and financial well-being by examining the role that shocks play in influencing subjective financial well-being; much of the extant research, by contrast, examines the role of financial shocks in driving more objective measures of financial well-being like making timely bill payments or skipping medical care. Second, to our knowledge this is the first study to examine both the relative impacts that different types of shocks (income, expense, and medical) have on subjective financial well-being as well as the degree to which different sources of liquidity (liquid assets, income, credit, and social resources) mitigate those impacts. Finally, this work features one of the few longitudinal analyses of the CFPB's financial well-being scale in the research literature, substantially extending the research on the temporal dynamics of this scale. These findings thus have implications for both how the field understands the construct of financial well-being, but also for how financial capability practitioners and educators think about and prioritize the use of different liquidity products to build household resilience to financial shocks.

\section{Background}

\subsection{Well-Being and Financial Circumstances}

There is a well-established literature exploring subjective well-being and its antecedents (e.g., Diener, 1994; Diener et al., 1985; Sirgy et al., 2006; Xiao and Li, 2011). Much of this research focuses specifically on the relationship between general well-being and financial measures such as poverty (Lever, 2004), income (Deaton, 2008; Easterlin, 2001), and wealth (Jivraj and Nazroo, 2014), typically finding a positive association between measures of an individual's economic security and their subjective well-being. However, these relationships are not necessarily constant across the income distribution, as income is a stronger predictor of well-being among individuals with lower incomes than it is for higher-income individuals (Diener and Biswas-Diener, 2002; Easterlin, 2001).

This body of work has also focused on the factors that promote stability and change in subjective well-being measures over time. In general, this research finds that individuals' well-being perceptions are a function of both stable characteristics such as personality 
traits as well as their response to various positive and negative life events (DeNeve and Cooper, 1998; Eid and Diener, 2004; Gomez et al., 2009), though individuals tend to adapt to these processes over time (Diener, 1994). This process of adaptation is referred to as the "hedonic treadmill" (Brickman and Campbell, 1971), in which a given life event can shift well-being perceptions in the short-term, but tend to shift back towards their baseline level over time. At the same time, this adaptation theory of well-being holds that different types of life events appear to differ in their effect on long-term well-being perceptions. For example, marriage may lead to a modest increase in well-being that quickly reverts to its baseline level, while unemployment events can lead to a sharp decline in well-being followed by a recovery to a level that is somewhat lower than baseline (Diener et al., 2006). In a meta-analysis, Luhmann and colleagues (2012) examined 188 longitudinal studies to explore how both family events such as divorce and work events such as unemployment affect individuals' well-being over time. This analysis found that the negative wellbeing effects of unemployment-which often entails a fairly substantial economic shock to a household-persisted longer than other life events. Other research on both individual unemployment (Winkelmann, 2014) and large scale economic shocks like the global financial crisis of 2007 and 2008 (Gonza and Burger, 2017; Welsch and Kühling, 2016) have found similar patterns concerning employment shocks and well-being.

A related perspective from developmental science, which focuses on the process of resilience, posits that individuals are capable of achieving positive adaptation and experience positive outcomes even in the event of adversity and challenging circumstances (Masten, 2001). Different assets (or resources) and risks tend to be associated with more positive or negative outcomes (Yates and Masten, 2012; Yates et al., 2015): having more resources (e.g., social capital) to rely on during the times of adversity can help build resilience and increase the likelihood of experiencing more positive outcomes, while a greater exposure to risks (e.g., living in a low-income neighborhood) can exacerbate the likelihood of negative outcomes. Existing research from the field of psychology points to a number of individual, social, and community factors that can improve an individual's capacity to cope with adversity and promote resilience (Davis et al., 2005; Gartland et al., 2019; Ungar and Theron, 2020). For example, better public infrastructure and availability of high-quality services can promote resilience among the disadvantaged (Davis et al., 2005), and multiple studies demonstrate that strong family support can act as a buffer that abates the general association between economic hardship and adverse outcomes (Hostinar and Miller, 2019). The theory of resilience therefore offers an important perspective on subjective well-being, showing a positive association between resilience and well-being (Liu et al., 2014; Windle et al., 2009) and also suggesting that, with appropriate support and protections, individuals experiencing great adversity in life can still build resilience and experience high levels of well-being. At the same time, there is some evidence that a lack of financial resilience is less important in promoting well-being than other factors such as a sense of control (Bialowolski et al., 2021).

In addition to the large literature on general indicators of well-being, there is also a robust body of research seeking to understand and characterize financial well-being, specifically. This research often focuses on relatively objective financial indicators such as intergenerational earnings (Chetty et al., 2017), household budgetary constraints (Schanzenbach et al., 2016), or the ability to cover an emergency expense without taking on debt (Board of Governors of the Federal Reserve System, 2017). A smaller body of research investigates how individuals perceive their own finances, which often focuses on financial worries or stress (Abbi, 2012; Shapiro and Burchell, 2012) or their financial satisfaction (Joo and Grable, 2004). Similar to the work on general well-being, research in this field typically finds a 
positive correlation between measures of financial security such as income and wealth and subjective financial perceptions (Friedline and West, 2016; Grable and Joo, 2006; Hsieh, 2004; Plagnol, 2011; Seghieri et al., 2006). The research on changes in subjective financial well-being perceptions over time finds similar patterns to the research on well-being more generally. That is, measures of financial well-being tend to be stable and even increasing over the life course (Hsieh, 2004; Plagnol, 2011; Plagnol and Easterlin, 2008); a pattern that holds across income groups after controlling for wealth and liabilities (Hansen et al., 2008). However, households who experience negative financial events tend to have lower levels of financial well-being (Joo and Grable, 2004; Ryan, 2012), and the effects of unemployment on financial well-being can persist for years (Ahn et al., 2004).

Though research on subjective financial perceptions has been relatively common, it was only recently that the field started coalescing around a common definition of subjective financial well-being. This movement has been facilitated by the CFPB's work in defining and measuring subjective financial well-being (CFPB, 2015). Subsequently, research has begun to explore the general levels of financial well-being in the population (CFPB, 2017 b) as well as how financial well-being correlates with household demographic, financial, and behavioral characteristics (e.g., Collins and Urban, 2020; Netemeyer et al., 2018). The conclusions of this research broadly indicate that higher incomes, assets, and other objective financial measures are all correlated with higher levels of subjective financial well-being. At the same time, research also finds that knowledge-based measures such as financial literacy, financial skills, and financial socialization are strong correlates of financial well-being (Collins and Urban, 2020; Lee et al., 2020; Warmath and Zimmerman, 2019; Zhao and Zhang, 2020), though a household's objective financial situation appears to be a stronger predictor of subjective financial well-being than their financial knowledge (Walker et al., 2018).

Our research builds on the growing body of work around subjective financial well-being by conducting a detailed analysis of the impact of various types of financial shocks on subjective financial well-being, as well as the degree to which different liquidity sources can play a protective role in supporting a sense of financial well-being in the event of a shock.

\subsection{The Prevalence and Impact of Financial Shocks}

Negative financial shocks can result from either decreases in income, such as the loss of a job or a reduction in work hours, or increases in expenses from events like health emergencies, expensive car or home repairs, or legal expenses like a divorce or expensive fines. These shocks are often unexpected and have been estimated to cost between $\$ 1,500$ and $\$ 2,000$ on average, thus potentially claiming a considerable portion of many households' income (Collins and Gjertson, 2013; Searle and Köppe, 2014). These shocks are common, as a quarter of respondents to the Survey of Household Economics and Decisionmaking reported that they had lost a job within that year (BGFRS, 2016), while an analysis of survey data by Pew Charitable Trusts showed that 60 percent of households experienced some type of expenditure shock in the prior 12 months (Pew Charitable Trusts, 2015).

Though households across the income spectrum may be vulnerable to financial shocks, the risks are particularly acute for LMI households. LMI households are more likely to experience financial shocks (Acs et al., 2009; Chase et al., 2011) and the costs of many of these shocks will, by definition, consume more of an LMI household's budget relative to a higher income household. At the same time, LMI households are less likely to have sufficient emergency savings to buffer them against these shocks BGFRS, 2016; Collins and 
Gjertson, 2013). This combination of an increased risk of shocks and limited savings to buffer against them may introduce a high degree of volatility into LMI households' sense of financial well-being.

One of the primary ways that financial shocks can impact the well-being of households is through an increased risk of experiencing a variety of material and medical hardships. The relationship between financial shocks and these hardships is well-documented in the literature, which finds that financial shocks are associated with increased rates of skipping bills (McKernan et al., 2009), food insecurity (Leete and Bania, 2010), and missed housing payments and skipped medical care (Despard et al., 2018). Though there is a substantial body of research on the relationship between financial shocks and relatively objective measures like hardships, research on the relationship between financial shocks and relatively subjective measures of financial well-being is more limited. The existing research on the subject indicates that shocks are associated with a decline in subjective financial wellbeing. The CFPB's study of financial well-being in the general U.S population found that households experiencing a negative financial shock in the prior 12 months had a significantly lower reported financial well-being score than those households who did not experience a negative financial shock (CFPB, 2017b). Other research on a sample of LMI households explored the correlation between different financial shocks and subjective financial well-being and found that, controlling for an array of demographic and financial characteristics, all measured negative financial shocks were associated with significantly lower levels financial well-being (Roll et al., 2021). This research also finds some evidence that negative income shocks may be more strongly associated with subjective financial wellbeing declines than expense shocks. Finally, research examining the relationship between experiencing material hardships such as skipped housing payments and difficulties in keeping up with essential bills-hardships which are often the consequence of experiencing negative financial shocks - has found a negative association between these hardships and subjective financial well-being (Aboagye and Jung, 2018; Comerton-Forde et al., 2020).

\subsection{Liquidity as a Buffer against Shocks}

Emerging alongside the research on the relationships between financial shocks and objective and subjective measures of financial well-being is a literature on how access to financial resources can build financial resilience and help households mitigate or recover from the adverse impacts of financial shocks. Financial resilience can be conceptualized and operationalized using four components: economic resources (e.g., savings, income), financial resources (e.g., access to credit), financial knowledge and behavior (e.g., knowledge of financial products and services), and social capital (e.g., social connections, access to social support in times of crisis) (Salignac et al., 2019). We discuss many of these components in detail below.

Access to liquidity - which can take the form of income flows, savings, credit, and social resources-has been shown to mitigate the effects of financial shocks on an array of household outcomes. Central to this body of work is the role that emergency savings - or the money set aside in anticipation of income uncertainty (Carroll, 1997) and expenditure increases (Chase et al., 2011) - has in buffering households against the negative effects of financial shocks. The research on emergency savings shows that LMI households with even modest levels of savings experience lower rates of deprivation and hardship following an income shock than LMI households lacking savings (McKernan et al., 2009; Mills and Amick, 2010), and that saving even small amounts 
for emergencies is associated with fewer hardships in the future (Gjertson, 2016; Sabat and Gallagher, 2019).

Despite the protective benefits of emergency savings, LMI households find it challenging to build emergency savings for a variety of reasons including budgetary constraints (Bureau of Labor Statistics, 2017; Schanzenbach et al., 2016), a lack of access to banking services that provide affordable credit and short-term savings options (Barr, 2004; Blank and Barr, 2009; Mullainathan and Shafir, 2009), and asset limits on public programs like the Supplemental Nutrition Assistance Program that can deter savings behaviors for fear of having benefits cut (Neuberger et al., 2006; O'Brien, 2008; Sherraden and Barr, 2005).

Households that lack emergency savings have other options to respond to shocks. In their review of 80 articles on households' ability to meet unexpected expenses, Collins and Gjertson (2013) examined the resources that LMI households turn to in financial emergencies. They found that households without emergency savings most typically borrowed money through credit cards or through their social resources (e.g., from friends or family) in the event of a financial need. Both credit cards and informal borrowing from friends and family have their advantages and drawbacks. Credit cards can provide a reliable means of managing drops in income or spikes in expenses. The interest rates are better than those for many other sources of short-term credit such as payday loans, and credit cards allow people to pay down debt over extended periods of time. However, many LMI households cannot access credit cards (Barr, 2004) and those that have access to credit cards are vulnerable to debt traps: Interest will accrue and compound on their debt over time if they fail to pay more than the monthly minimum payment, and access to low-cost credit may be lost if they fall behind on their payments.

Another potential source of liquidity in the event of a financial shock is a household's social and familial network, who may provide direct financial support in the form of cash gifts or loans. In informal lending arrangements, borrowers and lenders can adjust the terms of the loan without official contracts, late payments do not affect the borrower's official credit record, and borrowers can avoid higher cost alternatives. As such, borrowing from or relying on friends and family in the event of a financial shock may present an attractive alternative to relying on traditional credit (if available), alternative financial services like payday loans (which typically have high borrowing costs), or even relying on liquid assets. However, reliance on informal borrowing from friends and family can potentially perpetuate hardship within these networks and within communities that must disproportionately rely on informal financial support (Chiteji and Hamilton, 2005).

As with the research on the relationship between financial shocks and financial wellbeing, there is a large body of work on the effects of liquidity on objective measures of well-being, but a relative lack of research on the relationship between liquidity and subjective financial well-being measures. The CFPB's research demonstrates that liquid savings ownership and the capacity to absorb unexpected expenses were the single largest predictors of subjective financial well-being (CFPB, 2017b). Other research on an LMI sample of households found similar results, with the ability to access $\$ 2,000$ in the event of an emergency being associated with large increases in financial well-being scores (Bufe et al., 2019; Sun et al., 2018). However, this body of research remains largely descriptive or relies on cross-sectional data. 


\section{Theoretical Expectations}

The existing literature on the relationship between financial shocks, subjective financial well-being, and liquidity access indicates that, despite relative long-term stability in wellbeing perceptions, households facing financial shocks will experience short-term declines in subjective financial well-being, and that households who lack access to different forms of liquidity will experience larger subjective financial well-being decreases than those with access to a given source of liquidity. Our study builds on this literature by examining the roles that different types of shocks (e.g., income, expense, medical) and different types of liquidity (e.g., savings, credit, income, and social networks) have in driving these relationships. We anticipate both that households experiencing a given financial shock will experience significant declines in financial well-being relative to those not experiencing a given shock, and that households with access to a given source of liquidity will experience smaller declines in financial well-being following a financial shock than those without access to a given form of liquidity.

While there is relatively limited literature directly comparing the impact of different types of financial shocks on subjective well-being measures, the existing research points to job loss (e.g., Ahn et al., 2004) and negative income shocks (Heflin, 2016) as having acute negative impacts on well-being measures. Job and income loss may pose particular risks for households that lead to increases in expenses or debt, as income is required to cover many regular expenses that cannot be deferred without risk of serious hardships (food insecurity, utility shutoffs, evictions, etc.) and job/income loss can often persist for unspecified periods of time. By contrast, expense or debt increases (e.g., a health emergency, an unexpected car repair) may be difficult for households to afford, but they are often one-time expenses that households may cover through a variety of ways (taking on debt, working more hours, deferring payments, etc.).

Additionally, different types of liquidity may also be more or less effective in insulating households from the effects of financial shocks. Though there is limited research directly comparing the financial well-being impacts of being able to access different sources of liquidity, the existing literature does point to liquid assets being a particularly important correlate of both objective (Collins and Gjertson, 2013; Gallagher and Sabat, 2018) and subjective (Sun et al., 2018; CFPB, 2017b) financial well-being. Conceptually, liquid assets may be a particularly effective buffer against financial shocks as they allow households to fully or partially cover the shock without cutting back on expenses or taking on formal (e.g., credit cards, payday loans) or informal (e.g., borrowing from friends or family) sources of debt that need to be paid back over time and often come with high interest rates or fees. As such, we expect that access to liquid assets will be a more effective buffer against the financial well-being impacts of a given financial shock than other sources of liquidity.

\section{Methods}

\subsection{Data}

To explore the impact of financial shocks on financial well-being, and the extent to which different sources of liquidity can mitigate these impacts, this paper uses data from the 
longitudinal 2018 Household Financial Survey (HFS), which was offered to a random sample of tax households using TurboTax Freedom Edition software to prepare and file their taxes. ${ }^{1}$ Tax households may consist of taxpayers, their spouses, and any dependents they may claim on their income tax returns. In order to qualify for TurboTax Freedom Edition in 2018, a tax household needed to have a 2017 adjusted gross income of $\$ 33,000$ or less or be eligible for the Earned Income Tax Credit, though looser income restrictions were applied to active duty military households. The first wave of the 2018 HFS was administered online by the Social Policy Institute at Washington University in St. Louis between January and April of 2018 to LMI households immediately after they completed their taxes. Those who completed the first wave of the survey $(N=13,683)$ were invited to participate in the second survey wave, which was conducted roughly six months after tax-filing, between July and November of 2018. In total, 3,911 households responded to both waves of the 2018 HFS. These surveys included a large array of questions about tax household demographics, financial shocks, and hardships, as well as the ten-item CFPB Financial Well-Being Scale. While the unit of observation in this study is a tax household (hereafter household), demographic characteristics (e.g., age, gender) and self-assessed financial well-being correspond to those of a tax filer who completed taxes on behalf of their tax household.

\subsection{Sample}

For the analysis, we restricted the sample to households that completed both survey waves $(N=3,911)$, had non-missing information on key demographic and financial characteristics, a measure of financial well-being, and financial shocks $(N=3,735)$, and did not experience any income shock, expense shock, or medical shock at Wave $1(N=1,573)$. Restricting the sample to only those households who did not experience any shock in the first wave of the survey better allows us to isolate the financial well-being impact of experiencing a given shock between survey waves. We used three separate samples to estimate the impacts of income shocks, expense shocks, and medical shocks on subjective financial well-being. In each different sample, the comparison group includes households that did not report any financial shock at Wave 1 and did not experience the modeled shock (e.g., income, expense, or medical shocks) between Waves 1 and 2. The treatment group includes households that did not report any financial shock at Wave 1 and experienced the modeled shock between Waves 1 and 2. Households that experienced multiple shocks could be included in multiple samples. As summarized in Table 1, the experience of multiple shocks is relatively prevalent, particularly among treated households who, by definition, experienced at least one type of shock between Waves 1 and 2.

\subsection{Analytical Approach}

We explore the impacts of financial shocks on the subjective financial well-being of LMI households by applying a difference-in-differences framework combined with propensity score weighting. Households that experienced a given financial shock (e.g., an income, expense, or medical shock) between the first and second survey waves (treated households) may be systematically different from those that did not experience a given financial shock

\footnotetext{
1 TurboTax Freedom Edition is free tax-preparation software offered as part of the IRS Free File Alliance to LMI households that meet certain eligibility criteria (https://freefilealliance.org/).
} 


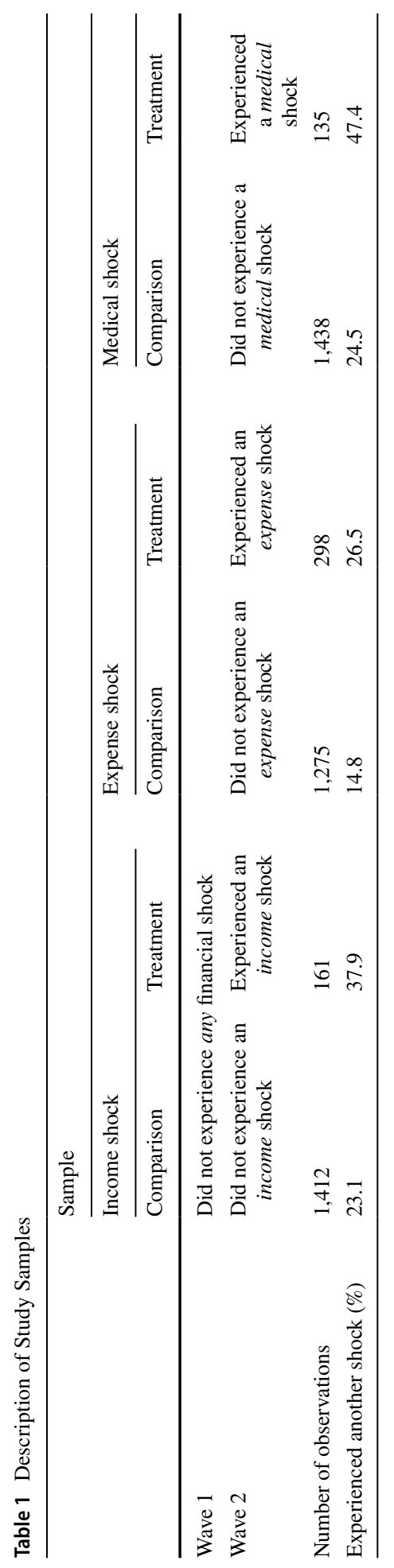


between the two survey waves (comparison households). Therefore, in each of these analyses, we employed separate propensity score models to balance the sample that experienced the modeled shock with the sample that did not on observable characteristics. ${ }^{2} \mathrm{We}$ generated the propensity scores using a probit regression model to predict a household's likelihood of experiencing a financial shock between the two survey waves based on their Wave 1 financial well-being as well as an array of demographic and financial characteristics measured at Wave 1 including gender, age, age squared, race/ethnicity, marital status, employment (part-time employed, full-time employed, or unemployed), health status, the presence of children, student status, self-assessed financial knowledge (rated on a 7-point scale from very low to very high), college attainment, and household gross income. Estimated propensity scores thus describe a household's probability of experiencing financial shocks conditional on baseline covariates. We used these probabilities to generate inverse probability of treatment weights, where $\left(w=\frac{1}{e}\right)$ are weights for treated households and $\left(w=\frac{1}{1-e}\right)$ are weights for untreated households, and $e$ represents a household's estimated propensity to experience a given shock (Guo \& Fraser, 2014). Inverse probability of treatment weighting using propensity scores helps adjust for observed dissimilarities between the groups, allowing us to estimate average treatment effects on a more balanced sample.

We then estimated difference-in-differences regression models of the following general form:

$$
F W B_{i t}=\alpha+\beta_{1} \text { Wave }_{t}+\beta_{2}\left(\text { Shock }_{i t} * \text { Wave }_{t}\right)+\beta_{3} \text { OtherShock }_{i t}+\theta_{i}+u_{i t}
$$

where the outcome, $F W B_{i t}$, represents household $i$ 's level of subjective financial well-being in survey wave $t$. Wave $e_{t}$ indicates whether the response was from the first or second wave of the survey, and $S h o c k_{i t}$ is a binary variable that indicates whether household $i$ experienced a given financial shock in the each wave of the survey. OtherShock $k_{i t}$ is a binary variable indicating whether or not the respondent experienced any other shock in each wave of the survey. $\theta_{i}$ captures household fixed effects and absorbs all time-invariant sources of variation within each household. $u_{i t}$ is an error term. Regression estimates were weighted using propensity score weights. We estimated separate regressions for three separate samples corresponding to three types of financial shocks - an income shock, an expense shock, and a medical shock. The coefficient on the interaction term, $\beta_{2}$, shows the change in subjective financial well-being for households experiencing a given shock in the six months between survey waves, relative to those that did not experience the shock, and can be interpreted as the marginal impact of the financial shock on the household's self-perceived financial

\footnotetext{
2 In the context of this study, combining difference-in-differences analysis with individual fixed effects and propensity score weighting has several advantages relative to other longitudinal data analysis approaches such as lagged dependent variable models or random effects modeling. First, by restricting our sample to only those who did not experience a financial shock at Wave 1 and then assessing the financial well-being impacts of experiencing a shock between Waves 1 and 2, we can be certain that our analytic sample is identical in terms of our key independent variable of interest (financial shock) in the baseline period. Second, the use of propensity score weights allows us further ensure that the treated and comparison households are similar on other observed characteristics that may be correlated with experiencing a given shock. This is especially important in the context of financial well-being measures, as research has found that lower levels of financial well-being are correlated with a higher likelihood of experiencing a financial shock (Roll et al., 2021). Finally, this approach allows us to incorporate individual-level fixed effects to account for any additional time-invariant characteristics that may influence our relationships of interest.
} 
well-being. The parameter $\beta_{1}$ captures the change in subjective financial well-being for households that did not experience a shock between the two waves of the survey.

This first part of our analysis addresses our first research question by investigating how different types of shocks impact the average financial well-being of the full analytical sample, allowing us to identify which types of financial shocks have the largest (and smallest) impacts on LMI households' sense of financial well-being. In the second part of our study, we explore the extent to which certain sources of liquidity can help mitigate the impacts of financial shocks on financial well-being. We address our second research question by splitting each of the income, expense, and medical shock samples by households' (a) gross income; (b) ability to rely on social networks; (c) liquid assets; and (d) ownership of a credit card. We then estimated Eq. 1 for each of these subsamples. Coefficients on the interaction terms were compared across the subgroups to test whether the impacts of income, expense, and medical shocks on subjective financial well-being were significantly different for different types of households. For example, we tested whether the coefficient on experiencing an income shock for households with access to social resources was significantly different than the income shock coefficient for those without social resources. This approach allowed us to explore the extent to which access to different types of liquidity could mitigate the adverse consequences of shocks.

\section{Measures}

\subsection{Outcome Variable}

The outcome variable in this analysis is subjective financial well-being, measured using the ten-item CFPB Financial Well-Being Scale. In both waves of the survey respondents were asked to react to the following ten statements (1) "I could handle a major unexpected expense"; (2) "I am securing my financial future"; (3) "Because of my money situation, I feel like I will never have the things I want in life"; (4) "I can enjoy life because of the way I'm managing my money"; (5) "I am just getting by financially"; (6) "I am concerned that the money I have or will save won't last"; (7) "Giving a gift for a wedding, birthday or other occasion would put a strain on my finances for the month"; (8) "I have money left over at the end of the month"; (9) "I am behind with my finances"; (10) "My finances control my life." Each of these statements were measured on a 5-item Likert scale. Response categories for the first six questions were "Completely, Very well, Somewhat, Very little, Not at all," and responses for the last four questions were "Always, Often, Sometimes, Rarely, Never." To derive financial well-being scores from respondents' answers we followed the procedure identified in the CFPB's technical report, applying a software-based scoring method that relies on Item Response Theory (CFPB, 2017). ${ }^{3}$

\footnotetext{
${ }^{3}$ We used the Stata package (pfwb.ado) to obtain financial well-being scores, which allowed us to estimate the scores even if responses to some financial well-being statements were missing. Derived financial wellbeing scores were set to missing only if respondents did not provide answers to any CFPB Financial WellBeing Scale items.
} 


\subsection{Independent Variables}

The primary independent variables capture a household's experiences of financial shocks. Our measures of shocks come from a survey question asking respondents whether their households experienced an array of financial shocks over the prior six months. These questions were identical in both waves of the survey. We focus on three types of financial shocks: (i) an income shock, which is equal to 1 if a household experienced an unexpected job loss, an unexpected reduction in income, or other job-related shock (e.g., getting laid off, terminated, or having work hours reduced by a current or former employer), and 0 otherwise; (ii) an expense shock, which is set to 1 if a household experienced an unexpected major repair of a house, appliance, or car, and 0 otherwise; and (iii) a medical shock, which equals 1 if households faced an unexpected major out-of-pocket medical expense (e.g., visit to an emergency room or hospitalization) or experienced a major medical event that required immediate professional treatment (e.g., the diagnosis of an illness, disease, injury, or an allergic reaction). As described above, respondents in each of our primary samples did not report experiencing any financial shock at Wave 1 (six months before tax filing) and may or may not have experienced a specific financial (income, expense, or medical) shock between Wave 1 and Wave 2 of the survey (six months following tax filing).

\subsection{Mitigating Factors}

Besides analyzing the average effects of financial shocks on the subjective financial wellbeing of LMI households, we also examined how certain financial resources can potentially mitigate the effects of financial shocks. We focus on four potential liquidity sources: (a) gross income; (b) ability to rely on social networks; (c) liquid assets; and (d) ownership of a credit card. Each of these factors may be important in mitigating the adverse impacts of shocks. To explore how each of these factors may mitigate the impact of financial shocks, we conduct subsample analyses comparing lower-income (under \$20,000) and higherincome (\$20,000 and above) LMI households; households that relied on social networks to help cover their day-to-day expenses and those that did not; households that reported owning less liquid assets (the sample median or below) and those that reported more liquid assets (above the sample median); and households that reported owning a credit card and those that did not. Each of these indicators was measured in the first wave of the survey and thus could not be affected by a financial shock experienced between the first and second survey waves.

\section{Limitations}

This analysis estimates the relationship between financial shocks and subjective financial well-being using observational data from a survey of LMI households. A potential source of bias in our estimates is that households experiencing financial shocks may differ systematically from households not experiencing financial shocks, and that factors other than the experience of certain financial shocks over time may be driving the changes in subjective financial well-being. To address this potential bias, our identification strategy relies on the fact that each household is observed at two time periods, which enables us to use fixed effects regression models to account for any time-invariant household traits 
that correlate with the experience of shocks and subjective financial well-being, such as demographic characteristics, prior exposure to financial shocks, or their attitudes towards savings and credit. Because we observe households during a period of just six months, we expect that many household characteristics (e.g., marital status, household size) remained unchanged during such short observation period and thus would be accounted for by the fixed effects. Moreover, combining the fixed effects models with propensity score weights allows us to correct for observable endogeneity in the experience of financial shocks and ensures that the treatment and comparison groups are statistically similar based on observable characteristics.

Yet, our estimates will be biased if there are some time-varying factors that changed over the six-month period and influenced both the experience of financial shocks and selfassessed financial well-being. One such factor could be the experience of other time-varying shocks. Indeed, as shown in Table 1, it is not unlikely that the experience of different types of financial shocks is interrelated. To the extent that the current analysis does not control for the presence of other time-varying shocks, our findings may be biased. In addition, given that multiple financial shocks were not uncommon in the treatment group, the current analysis may not adequately isolate the unique effect of each separate shock; controlling for other time-varying shocks would improve the measurement of our key independent variables. Finally, while the use of propensity score weights allows us to match households on observable characteristics, households may be dissimilar on unobservable factors. This is likely a lesser issue in our case given that the distributions of propensity scores are similar for the treatment and comparison groups, ${ }^{4}$ indicating relative group similarity on selected observables prior to weighting.

Besides the threats to internal validity, another limitation of this analysis concerns generalizability. Because our sample consists of LMI users of a tax-filing software who responded to both survey waves, had non-missing demographic and financial information, and experienced no financial shocks six months prior to tax filing, findings from this analysis may not be generalizable to the population of online LMI tax filers as well as the LMI population more generally. For example, the sampled households may be more technologically savvy since they can access online tax filing software, and are disproportionately likely to be single and enrolled in school. Since the current study does not incorporate population weights in addition to the propensity score weights, we cannot assess the generalizability of our findings.

Finally, another limitation of this analysis concerns the variables we use as mitigating factors in this study-income, the ability to rely on friends or family, liquid assets, and credit cards. While, conceptually, each of these factors plays a clear role in helping households smooth consumption in the event of a financial shock, we have limited information about the precise nature of each of these factors. For example, we cannot know if the reliance on friends or family comes in the form of cash gifts, informal loans, or non-monetary goods (e.g., food); nor do we observe potentially important factors like the interest rates on credit cards or their existing credit card debt relative to their credit limit. We also do not explicitly model households' levels of financial literacy—although we do include selfassessed financial knowledge in our propensity score estimation models-which could potentially act as a positive multiplier by allowing households to utilize their existing liquidity sources more optimally.

\footnotetext{
${ }^{4}$ Results available upon request.
} 
Table 2 Sample Characteristics

\begin{tabular}{|c|c|c|c|c|}
\hline \multirow[t]{4}{*}{ Characteristic } & \multicolumn{3}{|c|}{ Study sample (treatment $\&$ comparison groups) } & \multirow[t]{2}{*}{ Full sample } \\
\hline & Income shock & Expense shock & Medical shock & \\
\hline & $\mathrm{W}$ & $\mathrm{W}$ & $\mathrm{W}$ & UW \\
\hline & Mean & Mean & Mean & Mean \\
\hline \multicolumn{5}{|l|}{ First Wave of Survey } \\
\hline Financial well-being score & 55.1 & 55.3 & 55.1 & 55.3 \\
\hline Age (years) & 31.2 & 32.3 & 32.5 & 32.1 \\
\hline Male $(\%)$ & 52.2 & 50.5 & 49.2 & 50.1 \\
\hline \multicolumn{5}{|l|}{ Race/Ethnicity } \\
\hline White $(\%)$ & 71.4 & 72.2 & 72.3 & 72.2 \\
\hline Black $(\%)$ & 4.5 & 4.2 & 3.9 & 3.9 \\
\hline Hispanic (\%) & 9.6 & 8.5 & 9.6 & 8.0 \\
\hline Asian $(\%)$ & 9.9 & 9.8 & 8.4 & 10.4 \\
\hline Other $(\%)$ & 4.6 & 5.4 & 5.8 & 5.5 \\
\hline Married/lives with partner (\%) & 24.4 & 23.6 & 23.8 & 22.9 \\
\hline Any children in household (\%) & 16.3 & 16.0 & 15.2 & 16.3 \\
\hline Student (\%) & 37.4 & 37.4 & 38.6 & 37.6 \\
\hline Has a Bachelor's degree (\%) & 56.8 & 56.0 & 55.7 & 56.6 \\
\hline \multicolumn{5}{|l|}{ Employment status } \\
\hline Full-time (\%) & 45.9 & 45.1 & 44.8 & 45.3 \\
\hline Part-time (\%) & 34.7 & 33.8 & 32.9 & 34.1 \\
\hline Not employed (\%) & 19.4 & 21.1 & 22.3 & 20.7 \\
\hline Self-rated health is above average (\%) & 43.7 & 44.7 & 44.8 & 44.9 \\
\hline Gross income is over $\$ 20,000(\%)$ & 46.6 & 45.9 & 45.0 & 46.1 \\
\hline Ability to rely on social networks (\%) & 31.3 & 30.3 & 30.2 & 31.4 \\
\hline Median liquid assets $(\$)$ & 2,750 & 2,930 & 2,820 & 3,000 \\
\hline Ownership of a credit card (\%) & 66.4 & 68.9 & 69.0 & 67.3 \\
\hline Has health insurance (\%) & 91.4 & 92.8 & 93.1 & 93.1 \\
\hline Self-assessed financial knowledge (1-7) & 4.8 & 4.8 & 4.8 & 4.7 \\
\hline Observations & 1,573 & 1,573 & 1,573 & 1,573 \\
\hline Proportion of HHs in treatment group (\%) & 10.2 & 18.9 & 8.6 & 31.0 \\
\hline
\end{tabular}

$U W$, Unweighted sample; $W$, Propensity score weighted sample

\section{Findings}

\subsection{Sample Description}

Table 2 shows the demographic and financial characteristics and the average level of subjective financial well-being of LMI households included in each of three samples and measured at baseline (i.e., in the first wave of the survey). We present summary statistics for each weighted sample and the overall unweighted sample.

Looking at the three weighted study samples that contain both comparison and treatment groups for different types of financial shocks, the average demographic and financial 
Table 3 Overall Impact of Financial Shocks on Financial Well-Being in LMI Households (Propensity Score Weighted Models)

\begin{tabular}{lllll}
\hline \multicolumn{5}{l}{ Outcome: Financial Well-Being } \\
\cline { 2 - 5 } & Income Shock (1) & Expense Shock (2) & Medical Shock (3) & Any Shock (4) \\
\hline Wave*Shock & $-5.218^{* * *}$ & $-1.731^{* *}$ & -1.016 & $-2.776^{* * *}$ \\
& $(1.154)$ & $(0.589)$ & $(1.476)$ & $(0.556)$ \\
Wave & $-0.753^{*}$ & -0.486 & -0.398 & -0.291 \\
& $(0.376)$ & $(0.291)$ & $(0.428)$ & $(0.288)$ \\
Individual FE & Yes & Yes & Yes & Yes \\
Control for Other T2 Shock & Yes & Yes & Yes & 1,573 \\
Observations (unique HHs) & 1,573 & 1,573 & 1,573 & 0.052 \\
R-squared & 0.159 & 0.053 & 0.041 & No \\
\hline
\end{tabular}

Robust standard errors in parentheses. Statistical significance: $* * * p<0.001, * * p<0.01, * p<0.05$

characteristics were very similar across the samples. The average financial well-being score varied between 55.1 to 55.3 points, depending on the sample. This is similar to the average financial well-being score in the general population observed in the CFPB's study (54 points) and higher than that observed in a study of LMI households (48 points) (CFPB, 2017; Sun et al., 2018). The gender distribution was similar in each sample and the average respondent's age was over 31 years old. Survey takers in each sample were predominantly White (over 70 percent) and unmarried/living without a partner (approximately 75 percent). Less than one-fifth had a child living in a household, and over a third in each sample was enrolled in an educational program. Most respondents had at least a Bachelor's degree. Over 30 percent of respondents were employed part-time and approximately 20 percent were not employed. More than one-half of survey takers assessed their health as below average. The percent of households with gross incomes exceeding $\$ 20,000$ ranged from 45.0 to 46.6 , depending on the sample. Slightly less than one-third of the sample said that they could rely on social networks to cover day-to-day expenses, and slightly less than 70 percent in each sample reported owning a credit card. Over 90 percent of the sample had health insurance. The median amount of liquid assets ranged from $\$ 2,750$ to $\$ 3,000$ across different samples. The mean level of self-assessed financial knowledge was between 4.7 and 4.8 (on a 1 to 7 scale) across the samples. The weighted samples were generally very similar to the unweighted sample, though the levels of self-perceived financial well-being and liquid assets were slightly higher in the unweighted sample.

The experience of financial shocks was relatively common in our sample. 31.0 percent of households in the full sample experienced at least one financial shock. With regard to specific shocks, 10.2, 18.9, and 8.6 percent of households experienced income, expense, and medical shocks, respectively, meaning they are part of the treatment group in their respective samples.

\subsection{Impact of Financial Shocks on Financial Well-Being}

Table 3 describes the overall impacts of financial shocks on subjective financial well-being of LMI households from our difference-in-differences regression models using propensity score weights. For each modeled financial shock the sample is limited to households that did not report any financial shock in Wave 1 of the survey and may or may not have 
reported a modeled shock at Wave 2, which means that the sample composition differs across the samples though sample size remains the same.

Regression results suggest that experiencing financial shocks between survey waves generally lowered the average level of subjective financial well-being among LMI households. Specifically, an income shock reduced financial well-being scores by an average of 5.2 points $(9.4$ percent from the sample mean, $p<0.001)$. Experiencing an expense shock led to an average reduction in financial well-being scores of 1.7 points (3.1 percent from the sample mean, $p<0.01$ ). The coefficient on medical shocks was negative but statistically insignificant. The findings were consistent when we looked at the experience of any financial shock for the full sample. Comparing households that did not experience any financial shock between Waves 1 and 2 to those that reported experiencing a financial shock shows that the experience of any financial shock led to a 2.8 point reduction (5.1 percent from the sample mean, $p<0.001)$ in average financial well-being scores.

\subsection{Subgroup Analyses}

Next, we break down our weighted regression models by LMI households' access to different sources of liquidity at baseline to assess the degree to which liquidity access can mitigate the negative effects of shocks on subjective financial well-being. Table 4 compares the impacts of the financial shocks by household gross income. Lower-income LMI households, on average, experienced a 4.1 point $(p<0.001)$ decline in financial well-being scores as a result of an income shock. Income shocks reduced the average level of subjective financial well-being by 6.4 points $(p<0.01)$ in households whose gross income was at least \$20,000. The estimated difference between LMI households with lower and slightly higher incomes was not statistically significant. Average subjective financial well-being decreased by 2.6 points $(p<0.01)$ for LMI households with lower incomes that experienced an expense shock, and no statistically significant negative impact was observed for LMI households with higher incomes. The difference between these two negative coefficients was found to be statistically indistinguishable. Medical shocks did not have a significant impact on subjective financial well-With respect to households' ability to rely on social networks to cover day-to-day expenses (Table 5), an income shock reduced the average subjective financial well-being of LMI households that did not rely on social resources by 5.9 points $(p<0.001)$, but income shocks only reduced the financial well-being of those who could rely on social resources by 3.7 points $(p<0.01)$. However, the difference between the two negative values was statistically insignificant. The negative impact of expense shocks was statistically significant for households that were unable to rely on social resources: We find that these households saw their average financial well-being scores decrease by 2.4 points $(p<0.001)$ after facing an expense shock, while the effect on financial well-being for households that relied on social resources was not statistically significant. The difference between the coefficients was statistically significant at the 10 percent level. Finally, there was no significant impact of medical shocks on financial well-being across the subsamples, and the difference between the coefficients was not statistically significant.

Table 6 compares the impacts of financial shocks by a household's ownership of liquid assets. Here, the sample for each financial shock was split into two groups-above and at or below the median level of (unweighted) liquid assets reported during the first wave of the survey. After weighting, the median level of liquid assets was $\$ 2,750$ in the income shock sample, $\$ 2,930$ in the expense shock sample, and \$2,820 in the medical shock sample. Our results indicate that an income shock reduced financial well-being scores by an 


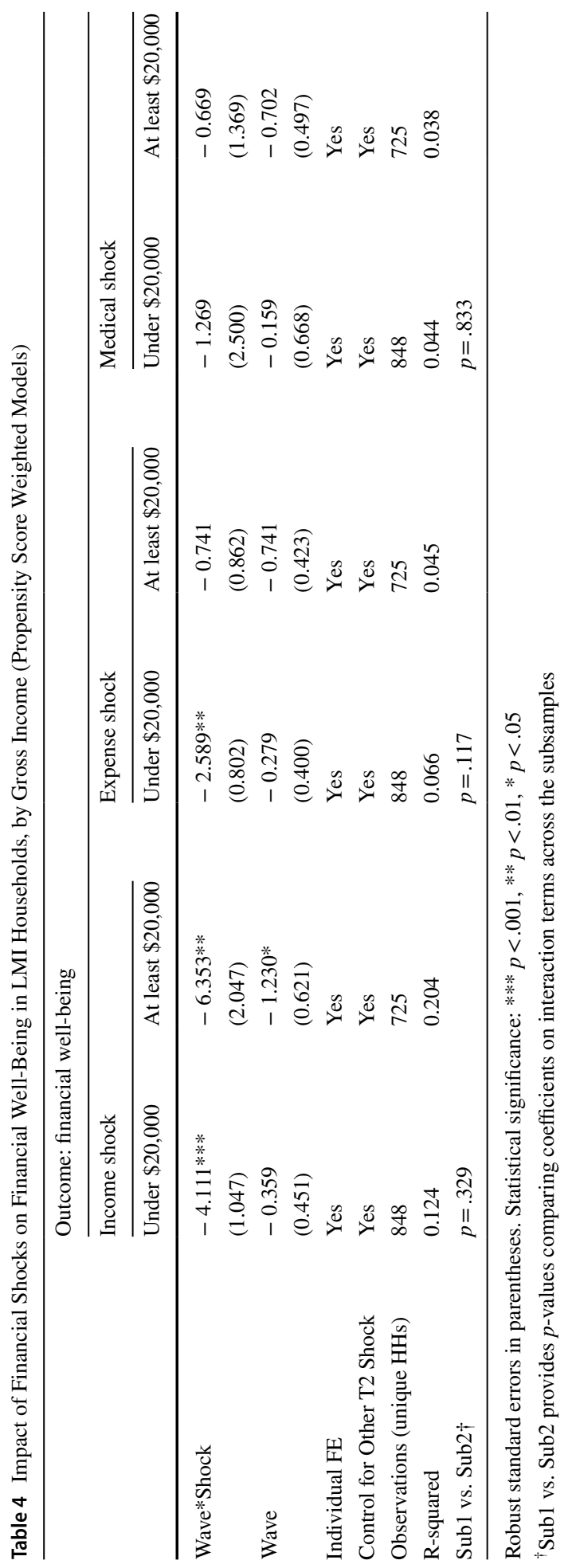




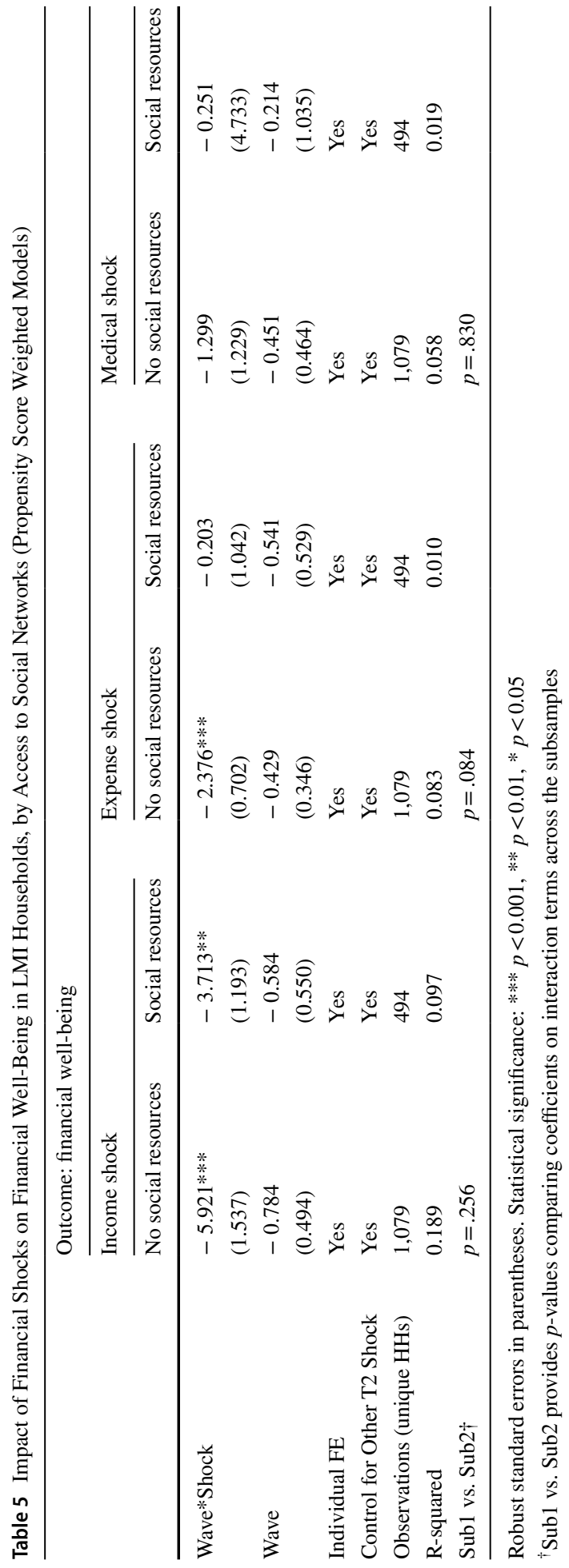




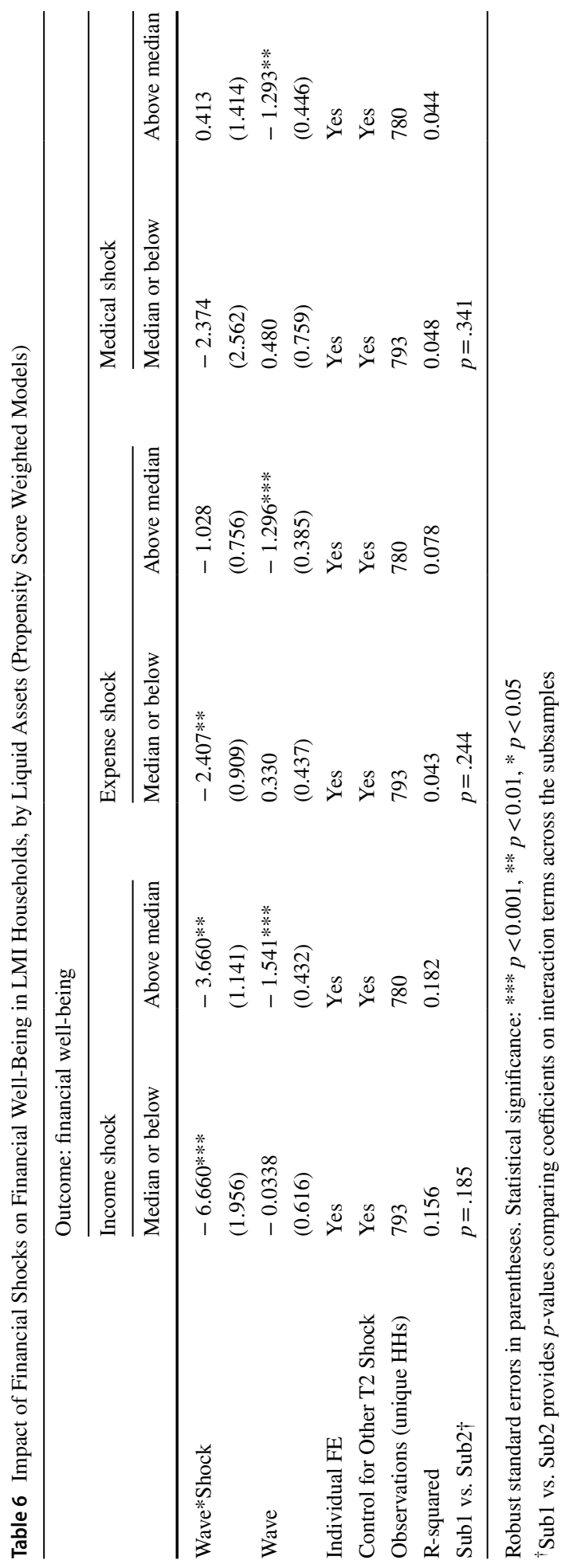


average of 6.7 points among households with lower levels of liquid assets $(p<0.001)$ and by 3.7 points among households with higher levels of liquid assets $(p<0.001)$; this 3.0 point gap between the coefficients was not statistically significant. Among those with fewer liquid assets, expense shocks led to a 2.4 point decline in financial well-being $(p<0.01)$. The impacts of expense shocks for households with higher levels of liquid assets and the difference between the estimated coefficients for these two groups were statistically insignificant. Finally, experiencing medical shocks had a statistically insignificant impact on subjective financial well-being of households for both subgroups.

For the final subsample comparison, we examined the impacts of financial shocks by a household's ownership of a credit card (Table 7). It is important to note that we do not know whether LMI households actually used credit cards to manage shocks, only that they had access to this source of liquidity. Our results suggest that income shocks reduced financial well-being scores for credit card owners by 6.0 points $(p<0.001)$, while for non-owners the reduction was 3.8 points $(p<0.05)$. Expense shocks reduced financial well-being scores among credit card owners by roughly 2.3 points $(p<0.01)$, but had a statistically insignificant negative impact for households that did not own credit cards. The comparison of these negative coefficient magnitudes suggested that any differences based on credit card ownership were not statistically distinguishable. As in the previous analyses, medical shocks had no statistically significant impact on subjective financial well-being of both credit card owners and non-owners.

\section{Discussion}

This paper presents one of the first rigorous longitudinal assessments of a new and promising scale for measuring an individual's overall financial condition while extending and validating the existing research on the importance of both economic volatility and liquidity buffers in determining a household's sense of financial security. Our results demonstrate that both income shocks and expense shocks lead to declines in subjective financial wellbeing, and that income shocks appear to be more harmful to an individual's sense of financial well-being; the decline in financial well-being scores associated with an income shock was over twice as large as decline associated with an expense shock. We also find that the coefficient on the relationship between medical shocks and subjective financial well-being was statistically insignificant.

These results imply a logical ordering to the severity of different types of shocks on subjective financial well-being over the six-month window for which we observe respondents. Income shocks are likely more sustained than expense shocks. The loss of a job or a notable reduction in hours likely has more implications for a household's sense of security than the expense shocks measured in this study, which may be one-time or short-term costs. Similarly, major out-of-pocket medical expenses may represent a one-time cost rather than a source of persistent budgetary constraint, and may also result in fewer direct constraints on a household's budget than other unexpected expenses like a car repair or home repair. Certain expenses may need to be handled immediately; if a refrigerator or a car breaks down a household may need to find a way to purchase repairs immediately in order to store food or get to work. A medical expense, by contrast, is typically imposed after medical service is already received, and may thus represent a less pressing obligation for households.

We also observe that the impact of different shocks on subjective financial well-being is, to a degree, conditional on whether respondents have access to different sources of 


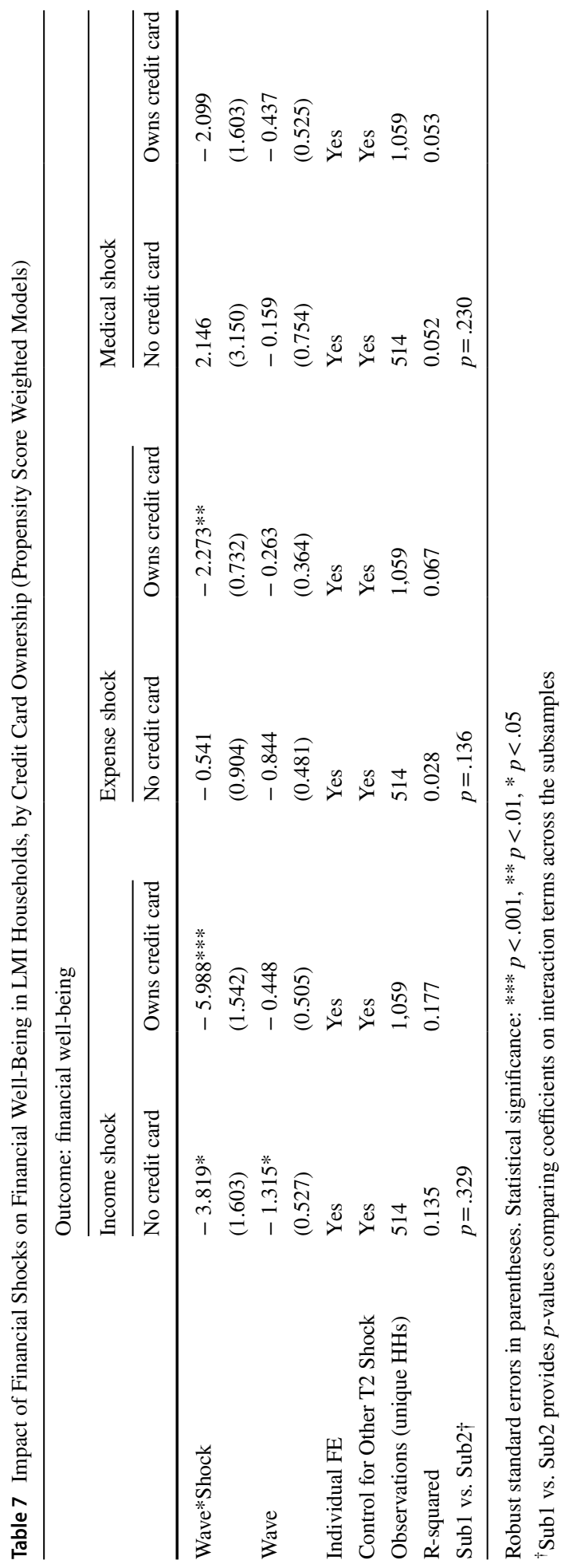


liquidity. Access to relatively high levels of liquid assets appears to attenuate the relationship between expense and medical shocks and financial well-being scores, but does not appear to influence the relationship between income shocks and self-assessed financial well-being. This may indicate that liquid assets are more effective at buffering LMI households against shocks that are limited in scope (like expenses associated with car repairs or home appliance repairs) than shocks that may persistently affect their finances (like the loss or reduction of an income stream).

Respondents with higher household incomes experienced directionally larger declines in subjective financial well-being when faced with income shocks, and respondents with lower household incomes tended to experience substantially larger declines in financial well-being scores when faced with expense shocks. This makes intuitive sense. A respondent with a higher-paying job may have a higher baseline level of subjective financial wellbeing (CFPB, 2017b) than a respondent with a lower-paying job, thus the loss of a higherpaying job (or the transition from higher pay to lower pay) may correspond to a larger decrease in financial well-being scores. At the same time, the experience of an expense shock may have more severe implications for a lower-income household than a higherincome household; a $\$ 1,000$ car repair, for example, necessarily consumes more of the budget of lower-income household than a higher-income household.

Directionally, respondents who could rely on outside help with their day-to-day expenses were more resilient to all measured shocks. However, the relationship between access to these social resources and changes in subjective financial well-being only approached significance in the case of expense shocks. This dynamic possibly indicates that social sources of financial support, such as friends or family members, may be more willing or able to help households offset one-time expenses than more persistent income shortfalls.

Interestingly, credit card ownership was the only form of liquidity access that was associated with a directional decline in financial well-being scores as a result of financial shocks. This implies that, while credit cards may function as a source of liquidity in the event of emergencies, the use of these cards may have additional drawbacks in terms of a household's sense of financial well-being. This may be due to the fact that covering a financial shock with a credit card does not immediately handle the expense in the same way that covering a shock with liquid assets or with help from social resources may. An expense put on a credit card is an expense that still needs to be covered, and households that take on debt in this way may feel less financially secure and thus report lower levels of subjective financial well-being.

In providing a detailed examination of the roles that both shocks and liquidity access play in influencing financial well-being, this paper extends both the robust literature on the relationship between shocks and subjective measures of general well-being (e.g., Gonza and Burger, 2017; Welsch and Kühling, 2016; Winkelmann, 2014) and the more limited literature on the relationship between financial volatility and subjective measures of financial well-being (e.g., Abbi, 2012; Prause et al., 2009; Roll et al., 2021). This literature holds that an individual's sense of well-being is a function of both stable factors like personality traits and reactions to both predictable and unpredictable life events (e.g., unemployment, marriage), and that individuals tend to adapt to these events over time (DeNeve and Cooper, 1998; Diener, 1994; Gomez et al., 2009). At the same time, certain major events like unemployment can lead to acute declines in well-being that persist for relatively long periods of time (Luhmann et al., 2012). Our study reinforces and extends this research by establishing that unexpected income losses are associated with much larger well-being declines than other types of financial shocks like expense and medical shocks. At the same time, we build on this literature by examining the relationship between financial shocks 
and financial well-being specifically within a low-income sample, and by examining the differential impact of these shocks based on the financial characteristics of this low-income sample (e.g., their income, assets, etc.). Our findings suggest that the financial well-being impacts of many financial shocks are the result of the interplay between the type of shock and households' financial characteristics. For example, income shocks appear to be directionally more impactful on low-income households with relatively high incomes $(\$ 20,000$ per year or more), while expense shocks are directionally less impactful on these households. These patterns indicate that research using general population averages to understand the relationships between different financial events and well-being may be missing more nuanced dynamics happening within these populations. Future research should focus on better identifying, measuring, and modeling these dynamics.

Additionally, while much of the financial security literature has focused on the role that one specific type of liquidity-liquid assets-plays in household financial security (e.g., Babiarz and Robb, 2014; Roll and Despard, 2020; Gjertson, 2016; McKernan et al., 2009; Mills and Amick, 2010; Sherraden and Sherraden, 2000), we are able to provide a broader overview of the interaction between a variety of liquidity sources and financial shocks, including liquid assets, income, social resources, and credit cards. Taking this broader perspective on liquidity is important because, even as many households have limited emergency savings, households still have many potential options to cover the costs of unexpected financial shocks (Collins and Gjertson, 2013). Yet even as we take this broader view of liquidity, our findings validate much of this literature by indicating that liquid assets can help attenuate the impact of shocks on household financial well-being, while access to credit cards - another common source of liquidity-does not appear to have a protective effect on financial well-being in the event of a shock. Interestingly, however, we also observe that the relationship between access to social resources, financial shocks, and financial well-being are similar to the relationships observed conditional on access to liquid assets. This may indicate the importance of better understanding the relationships that social and familial supports play in helping households manage financial volatility, and should be the subject for future research. At the same time, our estimates of these attenuation effects are imprecise, and should thus be interpreted with caution.

The dynamics observed in our analysis may help inform the design of policies and programs intended to improve the financial security of low-income populations. First, our findings suggest that different sources of liquidity may help offset different types of financial shocks. In particular, we observe that a number of protective factors-such as higher income flows, higher liquid assets, and access to social resources-can attenuate some of the impacts of certain financial shocks among economically disadvantaged populations. While increasing income is by no means easy for LMI households, practitioners working in financial capability fields should consider helping their populations access job training programs or provide them with tools to access and navigate the various opportunities for short-term contract work (often referred to as the "gig economy") to help them offset the costs of unplanned expenses. Likewise, more generous and welltargeted social welfare programs could help the most vulnerable households increase their disposable income and build financial assets, which could both reduce families' risk of facing adversities and increase their capacity to overcome unexpected emergencies. In terms of increasing liquid assets, it is important to identify key opportunities to help households build emergency savings, such as the receipt of the tax refund, or by implementing programs that can build emergency savings through payroll loan deductions. Finally, it is important to help households manage the use of social resources like friends and family members in order to better navigate the potential social and economic 
pitfalls associated with informal loan networks (Chiteji and Hamilton, 2005). Building social cohesion and encouraging households to rely on social resources may not be easy, since this means that local and regional governments have to increase their efforts to invest in community resources and engage more in promoting inclusion and equity.

Second, practitioners and policymakers could work on developing policies and programs to help households reduce the likelihood of facing unexpected, costly emergencies. For example, for the most part, the law currently does not require employers to notify employees much in advance about job termination. This makes it easy to terminate workers - particularly those employed in less stable, low-wage jobs-and increases the likelihood of workers facing unexpected income shocks upon termination. Similarly, irregular and unpredictable scheduling practices in many low-wage jobs can cause employees to experience frequent and unpredictable dips in their incomes. Improving laws and practices of work hour scheduling and procedures of worker termination can help many households avoid unexpected job losses and income dips. There are also ways in which policymakers and practitioners can help households reduce the severity of expense shocks, though these efforts may be more limited. For instance, by providing financial assistance to households to obtain better car insurance, households may be more equipped to weather costly and unexpected car repairs. Finally, more efforts may be needed to help households build financial resilience to overcome financial adversities relying on resources beyond the ones presented in this research, such as assisting with debt management, ensuring better access to affordable banking and insurance options, and improving access to community and government supports during adversities (Salignac et al., 2019).

At the same time, our research also points to some interesting implications for the use of the financial well-being scale as a tool for measuring the impact of financial security interventions. We observe that the reductions in financial well-being scores associated with some potentially major financial shocks such as job or income loss are, though statistically significant, relatively small. The coefficient on the reduction in subjective financial well-being associated with income loss is -5.22 , which is the equivalent of 0.39 standard deviations of the baseline level of subjective financial well-being. Given this, it may be difficult for many typical financial security interventions (such as incentivizing emergency savings, providing financial education, or promoting bank account opening) to make substantial impacts on financial well-being, at least in the short-term; these interventions are likely less impactful on a household's sense of financial wellbeing than, say, a job loss. More research will be required to assess the degree to which different interventions can impact subjective financial well-being in conjunction with more direct financial security outcome measures, such as account balances or credit scores.

Funding This paper was funded in part through a research contract with Abt Associates and the Consumer Financial Protection Bureau. The broader initiative on tax-time savings and financial well-being, of which this research project is one component, received outside funding from these sources: the U.S. Department of Treasury, the Annie E. Casey Foundation, the Intuit Financial Freedom Foundation, and the JPMorgan Chase Foundation. These organizations provided grant funding that partially covered the authors' salaries, the general collection of data (e.g., survey participation rewards), processing of data, and data analysis.

Data Availability Data are not available due to legal restrictions.

Code Availability The code used to generate research findings is available upon request. 
Disclaimer Statistical compilations disclosed in this document relate directly to the bona fide research of, and public policy discussions concerning, financial security of individuals and households as it relates to the tax filing process and more generally. Compilations follow Intuit's protocols to help ensure the privacy and confidentiality of customer tax data.

\section{Declarations}

Conflicts of interest The authors declare they have no conflicts of interest.

\section{References}

Abbi, S. (2012). A Need for Product Innovations to Help LMI Consumers Manage Financial Emergencies. Aboagye, J., \& Jung, J. Y. (2018). Debt holding, financial behavior, and financial satisfaction. Journal of Financial Counseling and Planning, 29(2), 208-218. https://doi.org/10.1891/1052-3073.29.2.208

Acs, G., Loprest, P., \& Nichols, A. (2009). Risk and Recovery: Documenting the Changing Risks to Family Incomes. In Perspectives on Low-Income Working Families Brief 9.

Ahn, N., García, J. R., \& Jimeno, J. F. (2004). The impact of unemployment on individual well-being in the EU. In European Network of Economic Policy Research Insitutes, Working Paper (Vol. 29). http:// www.enepri.org

Babiarz, P., \& Robb, C. A. (2014). Financial literacy and emergency saving. Journal of Family and Economic Issues, 35(1), 40-50. https://doi.org/10.1007/s10834-013-9369-9

Barr, M. S. (2004). Banking the Poor. Yale Journal on Regulation, 21(1). https://doi.org/10.1596/ 978-0-8213-7754-3

Bialowolski, P., Weziak-Bialowolska, D., \& McNeely, E. (2021). The Role of Financial Fragility and Financial Control for Well-Being. Social Indicators Research, 155(3), 1137-1157. https://doi.org/10.1007/ S11205-021-02627-5

Blank, R. M., \& Barr, M. S. (2009). Insufficient funds: Savings, assets, credit, and banking among lowincome households. Russell Sage Foundation.

Board of Governors of the Federal Reserve System. (2016). Report on the Economic Well-Being of U.S. Households in 2015.

Board of Governors of the Federal Reserve System. (2017). Report on the Economic Well-Being of U.S. Households in 2016.

Brickman, P., \& Campbell, D. T. (1971). Hedonic relativism and planning the good society. In M. H. Appley (Ed.), Adaptation level theory: A symposium (pp. 260-271). Academic Press.

Bufe, S., Sun, S., Roll, S. P., Kondratjeva, O., \& Grinstein-Weiss, M. (2019). How do changing financial circumstances relate to financial wellbeing? Evidence from a national survey. (SPI Research Brief No. 19-02). St. Louis, MO: Washington University, Social Policy Institute.

Consumer Financial Protection Bureau. (2015). Measuring Financial Well-Being. https://files.consumerfi nance.gov/f/201512_cfpb_financial-well-being-user-guide-scale.pdf

Consumer Financial Protection Bureau. (2017a). CFPB Financial Well-Being Scale. https://files.consumerfi nance.gov/f/documents/201705_cfpb_financial-well-being-scale-technical-report.pdf

Consumer Financial Protection Bureau. (2017b). Financial Well-Being in America. https://files.consumerfi nance.gov/f/documents/201709_cfpb_financial-well-being-in-America.pdf

Bureau of Labor Statistics. (2017). Income before taxes: Annual expenditure means, shares, standard errors, and coefficients of variation, Consumer Expenditure Survey, 2017.

Bureau of Labor Statistics. (2019). Labor force statistics from the Current Population Survey, seasonally adjusted unemployment rate. https://data.bls.gov/timeseries/LNS14000000

Carroll, C. D. (1997). Buffer-stock saving and the life cycle/permanent income hypothesis. Quarterly Journal of Economics, 112(1), 1-55. https://doi.org/10.1162/003355397555109

Chase, S., Gjertson, L., Collins, J. M., Chase, S., Jertson, L. G., \& Collins, J. M. (2011). Coming up with cash in a pinch: Emergency savings and its alternatives. http://citeseerx.ist.psu.edu/viewdoc/summa ry?doi=10.1.1.369.4498

Chetty, R., Grusky, D., Hell, M., Hendren, N., Manduca, R., \& Narang, J. (2017). The fading American dream: Trends in absolute income mobility since 1940. Science, 356(6336), 398-406.

Chiteji, N., \& Hamilton, D. (2005). Inclusion in the American dream. In M. Sherraden (Ed.), Inclusion in the American Dream: Assets, Poverty, and Public Policy. Oxford University Press.

Collins, J. M., \& Gjertson, L. (2013). Emergency savings for low-income consumers. Focus, 30(1), $12-17$. 
Collins, J. M., \& Urban, C. (2020). Measuring financial well-being over the lifecourse. European Journal of Finance, 26(4-5), 341-359. https://doi.org/10.1080/1351847X.2019.1682631

Comerton-Forde, C., de New, J., Salamanca, N., Ribar, D. C., Nicastro, A., \& Ross, J. (2020). Measuring Financial Wellbeing with Self-Reported and Bank-Record Data. http://ftp.iza.org/dp13884.pdf

Davis, R., Cook, D., \& Cohen, L. (2005). A Community Resilience Approach to Reducing Ethnic and Racial Disparities in Health. American Journal of Public Health, 95(12), 2168. https://doi.org/10. 2105/AJPH.2004.050146

Deaton, A. (2008). Income, health, and well-being around the world: Evidence from the Gallup World Poll. Journal of Economic Perspectives, 22(2), 53-72. https://doi.org/10.1257/jep.22.2.53

DeNeve, K. M., \& Cooper, H. (1998). The Happy Personality: A Meta-Analysis of 137 Personality Traits and Subjective Well-Being. Psychological Bulletin, 124(2), 197-229. https://doi.org/10.1037/00332909.124.2.197

Despard, M. R., Grinstein-Weiss, M., Guo, S., Taylor, S., \& Russell, B. (2018). Financial Shocks, Liquid Assets, and Material Hardship in Low- and Moderate-Income Households: Differences by Race. Journal of Economics, Race, and Policy, 1(4), 205-216. https://doi.org/10.1007/s41996-018-0011-y

Diener, E. (1994). Assessing subjective well-being: Progress and opportunities. Social Indicators Research, 31(2), 103-157. https://doi.org/10.1007/BF01207052

Diener, E., \& Biswas-Diener, R. (2002). Will money increase subjective well-being? A literature review and guide to needed research. Social Indicators Research, 57(2), 119-169. https://doi.org/10.1023/A: 1014411319119

Diener, E., Emmons, R. A., Larsem, R. J., \& Griffin, S. (1985). The Satisfaction With Life Scale. Journal of Personality Assessment, 49(1), 71-75. https://doi.org/10.1207/s15327752jpa4901_13

Diener, E., Lucas, R. E., \& Scollon, C. N. (2006). Beyond the hedonic treadmill: Revising the adaptation theory of well-being. American Psychologist, 61(4), 305-314. https://doi.org/10.1037/0003-066X. 61.4.305

Easterlin, R. A. (2001). Income and happiness: Towards a unified theory. Economic Journal, 111(473), 465-484. https://doi.org/10.1111/1468-0297.00646

Eid, M., \& Diener, E. (2004). Global judgments of subjective well-being: Situational variability and longterm stability. Social Indicators Research, 65(3), 245-277. https://doi.org/10.1023/B:SOCI.00000 03801.89195.bc

Friedline, T., \& West, S. (2016). Financial Education is not Enough: Millennials May Need Financial Capability to Demonstrate Healthier Financial Behaviors. Journal of Family and Economic Issues, 37(4), 649-671. https://doi.org/10.1007/s10834-015-9475-y

Gallagher, E. A., \& Sabat, J. (2018). Cash on Hand Is Critical for Avoiding Hardship. Federal Reserve Bank of St. Louis. https://www.stlouisfed.org/publications/bridges/winter-2017-2018/cash-critical-for-avoid ing-hardship

Gartland, D., Riggs, E., Muyeen, S., Giallo, R., Afifi, T. O., MacMillan, H., Herrman, H., Bulford, E., \& Brown, S. J. (2019). What factors are associated with resilient outcomes in children exposed to social adversity? A systematic review. BMJ Open, 9(4), e024870. https://doi.org/10.1136/BMJOP EN-2018-024870

Gjertson, L. (2016). Emergency saving and household hardship. Journal of Family and Economic Issues, 37(1), 1-17. https://doi.org/10.1007/s10834-014-9434-Z

Gomez, V., Krings, F., Bangerter, A., \& Grob, A. (2009). The influence of personality and life events on subjective well-being from a life span perspective. Journal of Research in Personality, 43(3), 345-354. https://doi.org/10.1016/j.jrp.2008.12.014

Gonza, G., \& Burger, A. (2017). Subjective Well-Being During the 2008 Economic Crisis: Identification of Mediating and Moderating Factors. Journal of Happiness Studies, 18(6), 1763-1797. https://doi.org/ 10.1007/s10902-016-9797-y

Grable, J., \& Joo, S.-H. (2006). Student racial differences in credit card debt and financial behaviors and stress. College Student Journal, 40, 400-408.

Guo, S., \& Fraser, M. W. (2014). Propensity score analysis: Statistical methods and applications (2nd ed.). Los Angeles, CA.

Hansen, T., Slagsvold, B., \& Moum, T. (2008). Financial Satisfaction in Old Age: A Satisfaction Paradox or a Result of Accumulated Wealth? Social Indicators Research, 89(2), 323-347. https://doi.org/10.1007/ s11205-007-9234-z

Heflin, C. (2016). Family Instability and Material Hardship: Results from the 2008 Survey of Income and Program Participation. Journal of Family and Economic Issues, 37(3), 359-372. https://doi.org/10. 1007/s10834-016-9503-6 
Hostinar, C. E., \& Miller, G. E. (2019). Protective Factors for Youth Confronting Economic Hardship: Current Challenges and Future Avenues in Resilience Research. The American Psychologist, 74(6), 641. https://doi.org/10.1037/AMP0000520

Hsieh, C. M. (2004). Income and financial satisfaction among older adults in the United States. Social Indicators Research, 66(3), 249-266. https://doi.org/10.1023/B:SOCI.0000003585.94742.aa

Jivraj, S., \& Nazroo, J. (2014). Determinants of socioeconomic inequalities in subjective well-being in later life: A cross-country comparison in England and the USA. Quality of Life Research, 23(9), 25452558. https://doi.org/10.1007/s11136-014-0694-8

Joo, S. H., \& Grable, J. E. (2004). An exploratory framework of the determinants of financial satisfaction. Journal of Family and Economic Issues, 25(1), 25-50. https://doi.org/10.1023/B:JEEI.0000016722. $37994.9 \mathrm{f}$

Lee, J. M., Lee, J., \& Kim, K. T. (2020). Consumer Financial Well-Being: Knowledge is Not Enough. Journal of Family and Economic Issues, 41(2), 218-228. https://doi.org/10.1007/ s10834-019-09649-9

Leete, L., \& Bania, N. (2010). The effect of income shocks on food insufficiency. Review of Economics of the Household, 8(4), 505-526. https://doi.org/10.1007/s11150-009-9075-4

Lever, J. P. (2004). Poverty and subjective well-being in Mexico. Social Indicators Research, 68(1), 1-33. https://doi.org/10.1023/B:SOCI.0000025567.04153.46

Liu, Y., Wang, Z., Zhou, C., \& Li, T. (2014). Affect and self-esteem as mediators between trait resilience and psychological adjustment. Personality and Individual Differences, 66, 92-97. https://doi.org/ 10.1016/J.PAID.2014.03.023

Luhmann, M., Hofmann, W., Eid, M., \& Lucas, R. E. (2012). Subjective well-being and adaptation to life events: A meta-analysis. Journal of Personality and Social Psychology, 102(3), 592-615. https://doi.org/10.1037/a0025948

Masten, A. S. (2001). Ordinary Magic Resilience Processes in Development. American Psychologist, 56(3), 227-238. https://doi.org/10.1037/0003-066X.56.3.227

McKernan, S., Ratcliffe, C., \& Vinopal, K. (2009). Do Assets Help Families Cope with Adverse Events?

Mills, G., \& Amick, J. (2010). Can Savings Help Overcome Income Instability? Perspectives on LowIncome Working Families Brief, 18.

Mullainathan, S., \& Shafir, E. (2009). Savings policy and decisionmaking in low-income households. In Insufficient Funds: Savings, Assets, Credit, and Banking Among Low-Income Households. Russell Sage Foundation.

Netemeyer, R. G., Warmath, D., Fernandes, D., \& Lynch, J. G. (2018). How Am i Doing? Perceived Financial Well-Being, Its Potential Antecedents, and Its Relation to Overall Well-Being. Journal of Consumer Research, 45(1), 68-89. https://doi.org/10.1093/jcr/ucx109

Neuberger, Z., Greenstein, R., \& Orszag, P. (2006). Barriers to saving. Communities and Banking, Sum, 25-27. https://ideas.repec.org/a/fip/fedbcb/y2006isump25-27.html

O'Brien, R. (2008). Ineligible to save? Asset limits and the saving behavior of welfare recipients. Journal of Community Practice, 16(2), 183-199. https://doi.org/10.1080/10705420801998003

Plagnol, A. C. (2011). Financial satisfaction over the life course: The influence of assets and liabilities. Journal of Economic Psychology, 32(1), 45-64. https://doi.org/10.1016/j.joep.2010.10.006

Plagnol, A. C., \& Easterlin, R. A. (2008). Aspirations, attainments, and satisfaction: Life cycle differences between American women and men. Journal of Happiness Studies, 9(4), 601-619. https:// doi.org/10.1007/s10902-008-9106-5

Prause, J., Dooley, D., \& Huh, J. (2009). Income volatility and psychological depression. American Journal of Community Psychology, 43(1-2), 57-70. https://doi.org/10.1007/s10464-008-9219-3

Roll, S., \& Despard, M. (2020). Income loss and financial distress during COVID-19: The protective role of liquid assets. Available at SSRN 3733862.

Roll, S., Kondratjeva, O., Bufe, S., Grinstein-Weiss, M., \& Skees, S. (2021). Assessing the short-term stability of financial well-being in low-and moderate-income households. Journal of Family and Economic Issues, 1-28.

Ryan, C. (2012). Responses to financial stress at life transition points (Occasional Paper No. 41).

Sabat, J., \& Gallagher, E. (2019). Rules of Thumb in Household Savings Decisions: Estimation Using Threshold Regression. SSRN Electronic Journal. https://doi.org/10.2139/ssrn.3455696

Salignac, F., Marjolin, A., Reeve, R., \& Muir, K. (2019). Conceptualizing and Measuring Financial Resilience: A Multidimensional Framework. Social Indicators Research, 145(1), 17-38. https://doi. org/10.1007/S11205-019-02100-4

Schanzenbach, D. W., Nunn, R., Bauer, L., \& Mumford, M. (2016). Where Does All the Money Go: Shifts in Household Spending Over the Past 30 Years.

Searle, B. A., \& Köppe, S. (2014). Assets, savings and wealth, and poverty: A review of evidence. 
Seghieri, C., Desantis, G., \& Tanturri, M. L. (2006). The richer, the happier? An empirical investigation in selected European countries. Social Indicators Research, 79(3), 455-476. https://doi.org/10. 1007/s11205-005-5394-X

Shapiro, G. K., \& Burchell, B. J. (2012). Measuring financial anxiety. Journal of Neuroscience, Psychology, and Economics. https://doi.org/10.1037/a0027647

Sherraden, M., \& Barr, M. S. (2005). Institutions and Inclusion in Saving Policy. Building Assets, Building Credit: Creating Wealth in Low-Income Communities, 2012(2004), 1-50. http://papers.ssrn. com/sol3/papers.cfm?abstract_id=722616

Sherraden, M., \& Sherraden, M. (2000). Asset building: Integrating research, education, and practice. Advances in Social Work, 1(1), 61-77. http://advancesinsocialwork.iupui.edu/index.php/advancesin socialwork/article/view/103

Sirgy, M. J., Michalos, A. C., Ferriss, A. L., Easterlin, R. A., Patrick, D., \& Pavot, W. (2006). The quality-of-life (QOL) research movement: Past, present, and future. In Social Indicators Research, 76(3), 343-466. https://doi.org/10.1007/s11205-005-2877-8

Sun, S., Kondratjeva, O., Roll, S. P., Despard, M., \& Grinstein-Weiss, M. (2018). Financial well-being in low- and moderate-income households: How does it compare to the general population? (SPI Research Brief No. 18-03). St. Louis, MO: Washington University, Social Policy Institute.

The Pew Charitable Trusts. (2015). The Role of Emergency Savings in Family Financial Security: How do Families Cope with Financial Shocks?

U.S. Bureau of the Census. (2017). Real Median Household Income in the United States [MEHOINUSA672N]. FRED, Federal Reserve Bank of St. Louis. https://fred.stlouisfed.org/series/MEHOINUSA6 $72 \mathrm{~N}$

Ungar, M., \& Theron, L. (2020). Resilience and mental health: How multisystemic processes contribute to positive outcomes. The Lancet Psychiatry, 7(5), 441-448. https://doi.org/10.1016/S2215-0366(19) 30434-1

Walker, J. T., Bocian, D. G., DeMarco, D., Freeman, B., \& Warmath, D. (2018). Understanding the Pathways to Financial Well-Being.

Warmath, D., \& Zimmerman, D. (2019). Financial Literacy as More than Knowledge: The Development of a Formative Scale through the Lens of Bloom's Domains of Knowledge. Journal of Consumer Affairs, 53(4), 1602-1629. https://doi.org/10.1111/joca.12286

Welsch, H., \& Kühling, J. (2016). How has the crisis of 2008-09 affected subjective well-being? Evidence from 25 OECD countries. Bulletin of Economic Research, 68(1), 34-54. https://doi.org/10.1111/boer. 12042

Windle, G., Woods, R. T., \& Markland, D. A. (2009). Living with Ill-Health in Older Age: The Role of a Resilient Personality. Journal of Happiness Studies, 11(6), 763-777. https://doi.org/10.1007/ S10902-009-9172-3

Winkelmann, R. (2014). Unemployment and happiness. IZA World of Labor. https://doi.org/10.15185/izawol.94

Xiao, J. J., \& Li, H. (2011). Sustainable Consumption and Life Satisfaction. Social Indicators Research, 104(2), 323-329. https://doi.org/10.1007/s11205-010-9746-9

Yates, T. M., \& Masten, A. S. (2012). Fostering the Future: Resilience Theory and the Practice of Positive Psychology. In A. P. Linley \& S. Joseph (Eds.), Positive Psychology in Practice (pp. 521-539). John Wiley \& Sons, Ltd. https://doi.org/10.1002/9780470939338.CH32

Yates, T. M., Tyrell, F. A., \& Masten, A. S. (2015). Resilience Theory and the Practice of Positive Psychology From Individuals to Societies. In S. Joseph (Ed.), Positive Psychology in Practice: Promoting Human Flourishing in Work, Health, Education, and Everyday Life. John Wiley \& Sons Inc.

Zhao, H., \& Zhang, L. (2020). Talking money at home: The value of family financial socialization. International Journal of Bank Marketing, 38(7), 1617-1634. https://doi.org/10.1108/IJBM-04-2020-0174

Publisher's Note Springer Nature remains neutral with regard to jurisdictional claims in published maps and institutional affiliations. 